\title{
An Analysis of Family Education in Paula Vogel's Plays
}

\author{
Qiaozhu Zhang* \\ Nanjing Normal University, Nanjing 210097, Jiangsu Province, China \\ *Corresponding author: Qiaozhu Zhang, 1181743862@qq.com
}

Copyright: ( $) 2022$ Author(s). This is an open-access article distributed under the terms of the Creative Commons Attribution License (CC BY 4.0), permitting distribution and reproduction in any medium, provided the original work is cited.

\begin{abstract}
As a famous female playwright, Paula Vogel focuses on traditional American families. Hot 'N' Throbbing, How I Learned to Drive, and The Long Christmas Ride Home are her three representative works that mainly reveal the contradictions and education problems in traditional American families, clearly presenting the influence of husband-wife relationship and parent-child relationship on the growth and development of children. She bravely criticizes the so-called "ideal family" promoted by the American society, leading people to reflect on and pay more attention to the education problems in traditional American families.
\end{abstract}

Keywords: Paula Vogel; Family education; Husband-wife relationship; Parent-child relationship

Online publication: January 24, 2022

\section{Introduction}

Upon the advent of the 21 st century, American drama is opening up a new and colorful dimension with a growing number of masterpieces that attract the attention of the public and critics. With the influence of the women's liberation movement since the 1960s, a large number of outstanding and innovative female playwrights have emerged, some of whom have won numerous theater awards, such as Megan Terry, Wendy Wasserstein, Martha Norman, Paula Vogel, and Lynn Nottage. Among all the American female playwrights, Paula Vogel has to be mentioned in view of her creative works, outstanding status, and comprehensive contribution to feminist drama. She has played a pivotal and irreplaceable role in the development of postmodern American drama, winning many awards, including the Obie Award for Best Drama and the Pulitzer Prize. Besides, she has also entered the American Theatre Hall of Fame in 2013, becoming one of the most famous and influential female playwrights in America. David Savran thinks that her plays represent "a revision and repossession of a highly masculinized textual practice ${ }^{[1]}$. Jill Dolan commented, "Paula Vogel tends to select sensitive, difficult, fraught issues to theatricalize and to spin them with a dramaturgy that's at once creative, highly imaginative, and brutally honest ${ }^{[2]}$. In addition, Vogel is not only a talented female playwright but also an excellent educator as she has trained a large number of excellent talents for the American drama world, like Nilo Cruz, Lynn Nottage, Adam Bock, and Bridget Carpenter. These excellent students, taught and led by Vogel, inherited her theatrical creation and gradually became new stars in the field of American drama. Thus, Vogel's outstanding contribution to American drama not only lies in her drama creation but also in her education and training of the next generation of drama novices.

Paula Vogel is a prolific playwright, who has produced over 20 plays during her creative career. Her plays tend to focus on highly controversial and major social issues, such as sexual relations, domestic 
violence, AIDS, homosexuality, ethics, and war. As a female playwright, Vogel attaches great importance to the portrayal of modern American family life, clearly pointing to the common educational difficulties and prominent contradictions in modern American families. Hot ' $N$ ' Throbbing, How I Learned to Drive, and The Long Christmas Ride Home are three major representative works of hers, which all focus on the conflicts within traditional American families. Hot ' $N$ ' Throbbing tells of Charlene who had divorced her husband but still has to endure his harassment and raise three children. Unfortunately, she was strangled to death by her husband. How I Learned to Drive is about the immoral affair between L'il Bit and her uncle, Peck. The Long Christmas Ride Home tells of a family journey on Christmas Eve; all the family members were not as happy as they were supposed to be, they were trapped in their minds and were not able to communicate with each other. In the three plays, Vogel depicts many real problems that occur in modern American families, focusing more on the profound impact of marital relationship and family environment on family education. Vogel criticizes the ideal dream of a "perfect family" promoted by the American society at that time and deeply reveals the shortcomings in the traditional American family education, thus arousing society's reflection and attention on family education.

\section{Influence of husband-wife relationship on children}

A good family relationship is the basis of building a harmonious and stable family. Family relationships directly reflect the closeness of family members, the stability of the family, the performance of family functions, the quality of family life, and have an impact on family education in different ways ${ }^{[3]}$. For every family, the relationship between husband and wife, parental quality, and the parent-child relationship influence the growth of children. A harmonious family cannot be separated from a healthy, stable, and loving relationship between husband and wife. The relationship between husband and wife as well as the quality of their parenting directly affect the growth of children. These are important factors that affect family education.

First of all, love between parents is the most important element for creating happy families and helping children grow with emotionally stable personalities. A good relationship between husband and wife is the key to creating a warm and harmonious family environment, which imperceptibly affects children's words and deeds. A relationship with confrontation, disputes, conflicts, and contradiction will directly affect children's emotions, thus leaving a huge impact on their values.

The relationship Vogel portrays in her plays is pathological and distorted. The attitude of the husband toward his wife is either assuming his wife as a private plaything to vent his sexual desire or with no love and affection. In Hot 'N' Throbbing, Charlene was so scared of her ex-husband; although they had already divorced, she was still harassed and threatened by him. Not only that, Charlene had to deal with the education problems of her children alone, and of the two children, her daughter's rebellion was beyond her control, while her son was filled with hatred and hostility toward his own father. In How I Learn to Drive, L'il Bit lacked care and guidance from her biological father, and she had to endure the insulting remarks about women from her grandfather. Besides, none of the female elders in the family were in a healthy or happy marriage. They often spoke about sexual relationships in front of her without any circumvention, which directly led to L'il Bit's inability to develop a correct perspective toward sexual relationships. In The Long Christmas Ride Home, the husband and wife barely had time to care for their three children. The husband thought about his mistress all the time, while the wife was anxious about her husband's infidelity. As a result, the three children were restless, without any power to refute or question, and they obviously had no expectation for this long Christmas journey. The parents were deeply affected by their emotions, indifference, and anger, putting the family at risk of falling apart.

Secondly, parents are the most direct, frequent, and important educators in the family ${ }^{[4]}$. Their views, words, and deeds are the main reference and imitation points of their children, especially during their 
childhood and youth. The influence of both parents on their children's education is also different. A German philosopher, Erich Fromm, once pointed out that although a father cannot represent nature, he represents another pole of human existence; that is, the world of thought, the world of science and technology, the world of law and order, as well as the world of experience and adventure ${ }^{[5]}$. Therefore, fathers lead the way to reason and order for their children.

In Hot 'N' Throbbing, How I Learn to Drive, and The Long Christmas Ride Home, Vogel's portrayal of fathers provides important and meaningful cases for the study of family education. In these three plays, three different fathers are portrayed: an alcoholic and violent domestic addict, an indulgent and irresponsible wastrel, as well as an unfaithful and incompetent betrayer. As fathers, they can neither be an ideal subject for imitation and reference nor help their children form healthy and accurate gender consciousness. Moreover, a father's influence on boys and girls is huge and different.

Some studies have suggested that boys who have lost their fathers often become feminine (passive and dependent) in their early childhood and excessively masculine (excessively aggressive and bullying); this may be a defense against a lack of masculine feelings ${ }^{[6]}$. On the other hand, fathers also affect their daughters' choice of a partner. A girl without a father is more likely to be more dependent on men and lack independence. If the father has a rough temperament, the girl may be biased against the opposite sex and may find it difficult to accept a love relationship.

In The Long Christmas Ride Home, Stephen, as a boy, is reserved, who rarely confides his thoughts to his parents or sisters. Without a father's guidance and living in a depressed, dull, indifferent family environment, Stefan is eager for freedom and approval for worldly morality. In How I Learn to Drive, L'il Bit lacks guidance and love from her father, and all her knowledge about sexual relationship come from her grandfather, grandmother, mother, and aunt. However, for both grandfathers and the female elders in her family, their marital life and sexual relationships are more or less associated with personal resentment and regret. Therefore, in the face of her gentle and patient uncle, she was not aware of his improper behavior, and she eventually fell into a stage of suffering and torture by the incoherent and immoral romance.

In summary, the relationship between husband and wife and the quality of their parenting play very important roles in family education. On the one hand, the relationship directly affects the overall family environment, which influences the children's emotions and cognition; on the other hand, fathers and mothers bear different parenting responsibilities in family education, which have a key impact on children's personality, gender awareness, and partner selection.

\section{Influence of parent-child relationship on children}

In a family relationship, in addition to marital relationship, the parent-child relationship is also equally important. It is an important link to maintain two generations and family inheritance.

According to Guang Ying, the parent-child relationship is the relationship between parents and children, which is between the two theme elements in family education. The study of family education itself is largely the study of the parent-child relationship. Different ways and contents of parent-child interaction result in different family education effects. The parent-child relationship is the unity of natural relationship and social relationship based on blood relationship and common life; in addition, it is based on the basic content of upbringing and support ${ }^{[7]}$.

A good parent-child relationship plays a very important role in the physical and mental development of children. Family, as one of the most important settings for personality development, with early, extensive, fundamental, lasting, uninterrupted, imperceptible, emotional guide for the building of moral personality and the development of moral socialization, plays an irreplaceable role ${ }^{[8]}$. The relationship between parents and their children, their attitude toward their children, and the way of raising their children directly affect their children's mental health and personality development. 
In Vogel's plays, the relationship between parents is cold, conflicted, and rigid. In such family environment, children tend to have some psychological issues, and their adult life tend to reflect certain personality defects.

For example, in How I Learn to Drive, without her father, L'il Bit had to endure the ridicule and contempt of her grandfather at home. Her grandfather's view of materializing women deeply influenced L'il Bit. Her grandfather believes that it is no use for a girl to obtain a college degree. Besides, when L'il Bit expresses her curiosity and confusion about sexual relations, her grandmother, mother, and aunt failed to set positive examples. She neither received care and guidance from the elders nor managed to establish a correct understanding of sexual relationships. Even when she left home for further studies, she was still unable to build love relationships with others. It required considerable effort from L'il Bit to seek for selfbreakthrough and heal the trauma brought by this shameful love experience with her uncle. In the early stage of her growth, if the elders in the family actively and patiently provided her guidance and help, she would not have experienced such a painful process.

In The Long Christmas Ride Home, the influence of the parent-child relationship on children is even more clear. In this play, the parents have been indifferent to their three children, either with deafness or rough interruption. The father only cared about his mistress, while the mother was so involved in the agitation of her husband's infidelity that she neglected her children. There is a huge gap between the parents and children, and the bridge of communication cannot be established in this family. The three children neither received rational guidance from their father nor emotional comfort from their mother. In addition, Vogel also depicts the adulthood of the children, and none of them owned a happy love relationship or marriage nor established a stable and harmonious relationship, just like their parents. This tragedy repeats itself across two generations, becoming a curse and nightmare for the whole family.

It can be seen that the parent-child relationship plays a vital role in children's psychological status and personality development. It also has a profound and lasting impact on their future. For children to cultivate and establish a healthy and comprehensive personality, parents need to provide appropriate guidance during their growth. Stable and smooth communication as well as interaction are important links in the building of a harmonious parent-child relationship.

\section{Conclusion}

Vogel's plays focus on traditional modern American families, detailing every family member: a desperate oppressed housewife, trapped in an unhappy marriage, an indifferent father who indulges and abandons responsibility, and children who lack care and guidance. She reveals the real side of the American family and presents the common contradictions and conflicts within families: domestic violence, divorce, and incest. Vogel leads the society to reflect on family life and education as well as to pay more attention to husband-wife and parent-child relationships, so as to encourage people to bravely face all aspects of family life with a new cognition and understanding to build a harmonious, stable, and happy modern family.

\section{Disclosure statement}

The author declares that there is no conflict of interest.

\section{References}

[1] Savran D, 2003, A Queer Sort of Materialism: Recontextualizing American Theatre, University of Michigan Press, Ann Arbor, 191.

[2] Dolan J, 1998, Reveiw of How I Learned to Drive. Theatre Journal, 50(1): 127. 
[3] Huang H, 2014, Family Education, East China Normal University Press, Shanghai, 81.

[4] Fei X, 1999, Fertility System, The Commercial Press, Shanghai, 61.

[5] Fromm E, 2002, The Art of Loving [Liu F, Trans.], Guangxi Normal University Press, Guilin, 37.

[6] Huang H, 2014, Family Education, East China Normal University Press, Shanghai, 71.

[7] Guang Y, 2000, Family Education in the View of Sociology, Tianjin Academy of Social Sciences Publishing House, 75.

[8] Wu H, Chen B, 2006, The Influence of Family Education on the Development of Minors' Moral Personality. Contemporary Youth Research, 2006(9): 73-75.

Publisher's note

Bio-Byword Scientific Publishing remains neutral with regard to jurisdictional claims in published maps and institutional affiliations. 